\title{
The Effects of Low FODMAP Diet on the Quality of Life and Gastrointestinal Symptoms in Children with Irritable Bowel Syndrome. A Pilot Study
}

\author{
Irritabl Bağırsak Sendromu (IBS) Tanılı Çocuklarda \\ Uygulanan Düşük FODMAP Diyetinin Yaşam Kalitesi ve \\ Gastrointestinal Semptomlar Üzerine Etkisi. Pilot Çalışma
}

\section{ABSTRACT}

Objective: Irritable bowel syndrome is a disease that negatively affects life. Recently, diet therapies have been emphasized. Our study, the aim was to investigate the effect of low FODMAP (fermented oligo-, di-, monosaccharide and polyols) diet on the frequency of gastrointestinal symptoms and the effects on quality of life in patients with IBS.

Method: 18 children aged between 7-18 years, who were diagnosed with IBS, followed by University of Health Sciences Izmir Dr. Behçet Uz Children's Diseases and Surgery Training and Research Hospital the Child Gastroenterology, Hepatology and Nutrition Clinic were included in the study. The appropriate KINDL scale was applied at the time of application and 2 weeks after the end of the low FODMAP diet. GIS symptoms of the week 0 and 6 KINDL results were compared. KINDL scale was applied to the families before and after dieting and the results were compared.

Results: The study was completed with 10 patients. The most common symptom was abdominal pain and it was present in all patients. All symptoms were found to decrease after diet but it was not significant. There was a significant increases in emotional well-being, family divisions and total KINDL results at the 6 th week of diet in the children In parent KINDL scales, the results were not considered significant. Conclusion: Despite there was a decrease in GIS related complaints and increase in quality of life in IBS patients who underwent low FODMAP diet, it has been found appropriate to continue the study with larger patient groups for longer follow-up periods.

Keywords: Irritable bowel syndrome, low FODMAP diet, KINDL scale

öz

Amaç: irritabl bağırsak sendromu yaşamı olumsuz etkileyen bir hastalıktır. Son zamanlarda diyet tedavileri üzerinde durulmaktadır. Çalışmamızda, iBS tanılı hastalara düşük FODMAP (fermente oligo, di, monosakkaritler ve polyoller) diyeti uygulanarak, gastrointestinal semptomların sıklığı ve yaşam kalitesi üzerine etkilerinin incelenmesi amaçland.

Yöntem: Sağlık Bilimleri Üniversitesi İzmir Dr. Behçet Uz Çocuk Hastalıkları ve Cerrahisi Eğitim Araştırma Hastanesi, Çocuk Gastroenteroloji, Hepatoloji ve Beslenme Kliniği tarafından takipli, iBS tanılı 7-18 yaş aralı̆̆ında 18 çocuk çalışmaya dahil edildi. Olgulara başvuru anında ve düşük FODMAP diyeti bitiminden 2 hafta sonra KINDL (Çocuklar İ̧̧in Genel Amaçlı Sağlıkla ilgili Yaşam Kalitesi Ölçeği) uygulandı. O. hafta ve 6. hafta KINDL sonuçları ve haftalık GiS semptomları karşılaştııılı. Ailelere de diyetten önce ve sonra KINDL ölçeği uygulanarak sonuçlar karşılaştırıldı.

Bulgular: Çalışma 10 hasta ile tamamlandı. Hastaların 6'sı erkek (\%60), 4'ü kız (\%40) idi. 7-12 yaş arası 4 (\%40), 13-17 yaş arası 6 (\%60) hasta vardı. Semptom olarak en sık karın ağrısı eşlik etmekte olup tüm hastalarda mevcuttu. Semptomların tamamının diyet sonrası azaldığı tespit edildi ancak anlamlı $p$ değeri elde edilemedi. Çocukların duygusal iyilik, aile bölümleri ve toplam KINDL sonuçlarında 6.hafta sonunda anlamlı artış saptandı. Ebeveyn KINDL öllçeklerinde ise sonuçlar istatistiksel olarak anlamlı değildi.

Sonuç: Hastalarda diyet ile genel iyilik hali ve bulgularda azalma sağlandığı görülse de, diyetin etkin ve geçerli olduğunun kanıtlanabilmesi için daha büyük gruplar ile daha uzun izlem süresini kapsayan çalışmalara ihtiyaç olduğunu düşünmekteyiz.

Anahtar kelimeler: Irritabl bağırsak sendromu, düşük FODMAP diyeti, KINDL ölçeği
Received: 14.08 .2020

Accepted: 13.04 .2021

First Publication: 20.09.2021

Cite as: İpek E, Ecevit ÇÖ, Akışın Z, Ata Teneler A, Bağ Ö. The effects of low FODMAP diet dn the quality of life and gastrointestinal symptoms in children with irritable bowel syndrome. A pilot study. İzmir Dr. Behçet Uz Çocuk Hast. Dergisi. 2021;11(3):240-6.

Ecem Iipek

SBÜ. Dr. Behçet Uz Çocuk Hastalıkları ve Cerrahisi Eğitim Araştırma

Hastanesi, Çocuk Kliniği, Izmir, Türkiye

ecemipekoner@gmail.com ORCID: 0000-0002-4250-7470

Ç.Ö. Ecevit 0000-0002-3980-8686 SBÜ. Dr. Behçet Uz Çocuk Hastalıkları ve Cerrahisi Eğitim Araştırma

Hastanesi, Çocuk Gastroenteroloji, Hepatoloji Ve Beslenme Kliniği, Izmir, Türkiye

Ö. Bağ 0000-0003-2178-4695 SBÜ. Dr. Behçet Uz Çocuk Hastalıkları ve Cerrahisi Eğitim Araştırma Hastanesi, Çocuk Kliniği, İzmir, Türkiye

Z. Akışın 0000-0002-2865-4810 SBÜ. Dr. Behçet Uz Çocuk Hastalıkları ve Cerrahisi Eğitim Araştırma Hastanesi, Diyetetik Kliniği, Izmir, Türkiye

A.A. Teneler 0000-0002-6054-1517 Ege Üniversitesi Tıp Fakültesi, Halk Sağlıüğı Anabilim Dalı, izmir, Türkiye

${ }^{\S}$ Bu makale, Ecem ipek Altınok'un uzmanlık tezinden üretilmiştir. 
E. İpek et al. The Effects of Low FODMAP Diet on the Quality of Life and Gastrointestinal Symptoms in Children with Irritable Bowel Syndrome.

\section{INTRODUCTION}

Irritable bowel syndrome (IBS) that causes abdominal discomfort is a common gastrointestinal system disease associated with changes in stool shape and frequency in defecation, which affects $20 \%$ of school- age children. Its pathophysiology can be explained partially with abnormal gastrointestinal motility, visceral hypersensitivity, low level inflammation, and psychological factors. Its etiology is complex and poorly understood, and there are many treatment methods developed, although very few are actually effective ${ }^{(1-4)}$.

Gastrointestinal symptoms encountered most frequently and causing discomfort in patients include abdominal pain, bloating, diarrhea, constipation, vomiting, and a sudden feeling of the need to defecate. Recently, the effect of diet on the development of symptoms has been understood in more detail, and different dietary treatments have begun to be applied. In randomized controlled studies, the Low FODMAP (fermented oligo-, di-, monosaccharide and polyols) diet has been shown to be effective on alleviation of gastrointestinal symptoms and for the treatment of IBS ${ }^{(5,6)}$.

Quality of life is a broader concept that includes personal well-being rather than personal health. The Generic Health-Related Quality of Life Scale for Children (KINDL) is used in children with various chronic illnesses and developmental problems to determine which aspects of life are more deeply affected due to disease or its treatment. There are three versions of the KINDL scale: Kiddy-KINDL (version implemented through the interviewer) for children 4-7 years old, Kid-KINDL for children 8-12 years old, and Kiddo-KINDL for adolescents 13-16 years old. In addition, there are two parent forms in which the quality of life of young children (4-7 years) and older children and adolescents (8-16 years) can be indirectly evaluated by their families. KINDL consists of six domains (physical well-being, emotional well-being, self-esteem, family, friends, and school) with the evaluation of a total quality of life ${ }^{(7)}$.
Studies have shown that children with IBS have a quality of life worse than healthy children. However, there is little data on the quality of life of these children during the posttreatment follow-up period ${ }^{(8)}$.

In this study, we aimed to examine the effects of low FODMAP diet on the frequency of gastrointestinal symptoms and quality of life in patients with IBS.

\section{MATERIALS and METHOD}

Because IBS does not have a specific biological marker, diagnosis of these patients is made based on symptoms. First of all, some examinations, which are the first step to rule out organic pathologies are performed. Rome III criteria are used for the diagnosis. To establish the diagnosis of IBS two of the following criteria associated with at least 3 attacks of abdominal pain per month persisting for the previous 3 months should be present: relief of pain with defecation, change in the frequency of defecation, and feçes.

A total of 18 children between 7-18 years of age diagnosed with IBS according to the Rome III criteria and followed up by University of Health Sciences Behçet Uz Pediatrics and Surgery Training and Research Hospital Pediatric Gastroenterology, Hepatology and Nutrition Clinic were included in the study. These children were all IBS patients who were followed up by this clinic during the study period extending from December 2016 to December 2017.

Patients who were followed up with a diagnosis of IBS but used medication within the previous week were not included in the study. Six of the 18 study patients on dietary treatment were excluded due to non-compliance with the diet plan. One patient was excluded from the study because of a diagnosis of FMF, and symptoms of another patient increased and required further investigation. The study was completed with the remaining ten patients.

Subjects were queried about family history, medication use, diets, presence of abdominal pain, bloating, diarrhea, constipation, nausea-vomiting, need for urgent defecation, loss of appetite, weight loss, abdominal pain at night, nocturnal defecation and fever. Hemogram, liver-kidney function tests, 
electrolytes, calcium-phosphorus levels, stool tests, abdominal ultrasonography findings, and standing direct abdominal radiographs were evaluated.

Our study was conducted based on the hypothesis "With a low FODMAP diet, the gastrointestinal symptoms of IBS patients will decrease and the quality of life of the IBS patients will improve." All patients diagnosed with irritable bowel syndrome and their families were informed about the study and their consent was obtained. Existing symptoms were identified and age-adjusted KINDL scales were applied to patients before starting dietary therapy for four weeks. Follow-up visits were implemented at $1,3,4$, and 6 (two weeks after the end of dietary treatment) weeks after the initiation of a low FODMAP diet. The symptoms were reevaluated at the follow-up visits so as to make comparisons. KINDL scale scores were calculated again two weeks after termination of the dietary therapy (sixth week). In our study, GIS symptoms and KINDL scale results were compared before implementation of the dietary plan, between one, four, and also six weeks after termination of the dietary therapy. Similarly, the changes in the results were evaluated by applying the KINDL scale scores to the parents before and after the treatment in the sixth week.

The low FODMAP diet is based on the removal of oligo-di-monosaccharides and polyols that can be fermented by intestinal bacteria. The low FODMAP diet does not contain monosaccharides (glucose, fructose, galactose, xylose, arabinose), disaccharides (sucrose, lactose, maltose, isomaltose) ,oligosaccharides (maltodextrin, refined sugars, fructo-oligosaccharide, soy), and polyols (sorbitol, mannitol, isomalt, lactitol(. Luminal distension and visceral hypersensitivity caused by these small molecules are prevented ${ }^{(9,10)}$. The adjustment of the diet together with collection of information about the patients was performed by a single dietician. Food lists containing low or high FODMAP were given to the patients. Full low FODMAP diet was applied for the first two weeks. Then in the remaining two weeks, food from the high FODMAP groups consumed in the daily routine were added to the diet at three-day intervals. The FODMAP dietary therapy was terminated at the end of four weeks.

SPSS (Statistical Package for Social Sciences- IBM Inc, Chicago, Illinois, USA) 22 Windows programs were used for statistical analysis. Mean, standard deviation and percentage distribution data were used for descriptive findings and KINDL scores. The McNemar test was used to evaluate the symptoms and the weekly controls were made using chi- square test. Use of average and standard deviation for parametric, and median and minimum-maximum values for nonparametric data was preferred. The t-test was used for parametric and Wilcoxon ranksum test for nonparametric measurements in the comparison of KINDL scores and the factors affecting the KINDL scores in independent groups,. Test results with $p<0.05$ were considered statistically significant. A post-hoc power analysis was calculated using the $\mathrm{G} *$ power computer program. The result of the posthoc power analysis was found to be $32 \%$ for our study, which has a one tailed hypothesis.

\section{RESULTS}

Six (60\%) male, and 4 (40\%) female 10 patients completed the study. Although the number of patients was low in our study, it was found that $30 \%$ of the patients had mixed type IBS, 30\% had constipation predominant IBS, $10 \%$ had diarrhea predominant IBS and type of IBS of $30 \%$ of the patients were not classified.

The complaints of the patients were urgency (60\%), constipation (50\%), anorexia (50\%) and diarrhea $(40 \%)$ in decreasing frequency. At the follow-up visits performed at the first and fourth weeks after the dietary therapy was started, it was found that the complaints of abdominal pain, bloating, diarrhea, constipation, vomiting, urgent defecation, anorexia, weight loss decreased but the $p$ value could not be obtained due to the limited number of study patients (Table 1 ).

The results observed at follow-up visits two weeks after the end of the dietary therapy were compared with the symptoms of Gl before the initiation of the dietary therapy. Abdominal pain decreased in $50 \%$, and constipation in $40 \%$ of the 
E. İpek et al. The Effects of Low FODMAP Diet on the Quality of Life and Gastrointestinal Symptoms in Children with Irritable Bowel Syndrome. A Pilot Study

Table 1. Comparison of symptoms of gastrointestinal tract week 1 and week $4(n=10)$.

\begin{tabular}{|c|c|c|c|c|c|}
\hline & \multicolumn{2}{|c|}{ Week 1} & \multicolumn{2}{|c|}{ Week 4} & \multirow[b]{2}{*}{$\begin{array}{c}p \\
\text { value }\end{array}$} \\
\hline & $\begin{array}{c}\text { Yes } \\
\text { n (\%) }\end{array}$ & $\begin{array}{c}\text { No } \\
\text { n (\%) }\end{array}$ & $\begin{array}{c}\text { Yes } \\
\text { n (\%) }\end{array}$ & $\begin{array}{c}\text { No } \\
n(\%)\end{array}$ & \\
\hline Abdominal pain & $7(70)$ & $3(30)$ & $4(40)$ & $6(60)$ & NA \\
\hline Diarrhea & $2(20)$ & $8(80)$ & $0(0)$ & $10(100)$ & NA \\
\hline Constipation & $4(40)$ & $6(60)$ & $3(30)$ & $7(70)$ & NA \\
\hline Vomiting & $2(0)$ & $8(80)$ & $0(0)$ & 10 (100) & NA \\
\hline $\begin{array}{c}\text { Urgent feeling of } \\
\text { defecation }\end{array}$ & $5(50)$ & $5(50)$ & $2(20)$ & $8(80)$ & NA \\
\hline Anorexia & $2(20)$ & $8(80)$ & $1(10)$ & $9(90)$ & NA \\
\hline Weight loss & $1(0)$ & $9(90)$ & $0(0)$ & 10 (100) & NA \\
\hline
\end{tabular}

Table 3. Comparison of Child-Adolescent KINDL scores before and after diet.

\begin{tabular}{lccc}
\hline & \multicolumn{2}{c}{$\begin{array}{c}\text { Department Score } \\
\text { Mean } \pm \text { Standard Deviation }\end{array}$} & \\
\cline { 2 - 3 } KINDL Subgroups & $\begin{array}{c}\text { Before diet } \\
\text { (Week 0) }\end{array}$ & $\begin{array}{c}\text { After Diet } \\
\text { (Week 6) }\end{array}$ & $\begin{array}{c}\text { p } \\
\text { value }\end{array}$ \\
\hline Physical well-being & $46.25 \pm 15.92$ & $53.75 \pm 15.36$ & 0.2 \\
Emotional well-being & $65.62 \pm 14.80$ & $79.32 \pm 13.19$ & 0.01 \\
Family Relationships & $45.62 \pm 8.86$ & $75.00 \pm 21.65$ & 0.01 \\
Friend Relationships & $72.50 \pm 16.97$ & $70.00 \pm 22.97$ & 0.76 \\
School & $63.75 \pm 17.12$ & $71.25 \pm 15.36$ & 0.14 \\
Total score & $59.58 \pm 9.69$ & $68.12 \pm 12.97$ & 0.039 \\
\hline
\end{tabular}

As the T-test failed to meet the conditions, the Wilcoxon signedranks test, a nonparametric measurement, was used to evaluate the self-esteem section. There were negative findings at the end of the 6th week in the results of the self-esteem section, but without any statistically significant intergroup difference ( $p=0.63)$.

cases, and urgency described in $50 \%$ of the patients persisted. While bloating was present in only one case $(10 \%)$, the complaints of diarrhea, vomiting, anorexia and weight loss were not observed in any case at the end of the dietary therapy (Table 2).

There was a significant increase in emotional well-being, family subscale and total KINDL scores after termination of the dietary therapy $(p=0.01$, $p=0.01$, and $p=0.039$ ). Though not statistically significant, there was a positive increase in the physical well-being and school subscale scores $(p=0.2$, and $p=0.14)$. The KINDL scores of the patients related to peer relationships were lower after the dietary therapy without statistically significant intergroup difference.
Table 2. Comparison of symptoms of gastrointestinal tract before and after low FODMAP diet.

\begin{tabular}{|c|c|c|c|c|c|}
\hline & \multicolumn{2}{|c|}{$\begin{array}{l}\text { Before Diet } \\
\text { (Week 0) }\end{array}$} & \multicolumn{2}{|c|}{$\begin{array}{c}\text { After Diet } \\
\text { (Week 6) }\end{array}$} & \multirow[b]{2}{*}{$\begin{array}{c}p \\
\text { value }\end{array}$} \\
\hline & $\begin{array}{l}\text { Yes } \\
\text { n (\%) }\end{array}$ & $\begin{array}{c}\text { No } \\
n(\%)\end{array}$ & $\begin{array}{c}\text { Yes } \\
\text { n (\%) }\end{array}$ & $\begin{array}{c}\text { No } \\
n(\%)\end{array}$ & \\
\hline Abdominal pain & $10(100)$ & $0(0)$ & $5(50)$ & $5(50)$ & NA \\
\hline Bloating & $7(70)$ & $3(30)$ & $1(10)$ & $9(90)$ & 0.07 \\
\hline Diarrhea & $4(40)$ & $6(60)$ & $0(0)$ & $10(100)$ & NA \\
\hline Constipation & $5(50)$ & $5(50)$ & $2(20)$ & $8(80)$ & 0.25 \\
\hline Vomiting & $2(0)$ & $8(80)$ & $0(0)$ & $10(100)$ & NA \\
\hline $\begin{array}{c}\text { Urgent feeling of } \\
\text { defecation }\end{array}$ & $6(60)$ & $4(40)$ & $3(30)$ & $7(70)$ & 0.25 \\
\hline Anorexia & $5(50)$ & $5(50)$ & $0(0)$ & $10(100)$ & NA \\
\hline Weight loss & $1(0)$ & $9(90)$ & $0(0)$ & $10(100)$ & NA \\
\hline
\end{tabular}

Table 4. Comparison of parental KINDL scores before and after diet.

\begin{tabular}{lccc}
\hline & \multicolumn{2}{c}{$\begin{array}{c}\text { Department Score } \\
\text { Mean士Standard Deviation }\end{array}$} & \\
\cline { 2 - 3 } KINDL Subgroups & $\begin{array}{c}\text { Before diet } \\
\text { (Week 0) }\end{array}$ & $\begin{array}{c}\text { After Diet } \\
\text { (Week 6) }\end{array}$ & $\begin{array}{c}\text { p } \\
\text { value }\end{array}$ \\
\hline Physical well-being & $51.87 \pm 19.77$ & $61.25 \pm 11.33$ & 0.14 \\
Self-esteem & $61.87 \pm 20.50$ & $66.25 \pm 20.87$ & 0.34 \\
Family Relationships & $75.62 \pm 23.28$ & $75.00 \pm 19.09$ & 0.92 \\
Friend Relationships & $73.75 \pm 19.72$ & $66.25 \pm 15.92$ & 0.18 \\
School & $68.12 \pm 16.78$ & $68.75 \pm 22.43$ & 0.93 \\
Total score & $65.62 \pm 14,96$ & $67.60 \pm 13.61$ & 0.65 \\
\hline
\end{tabular}

Although there were negative findings at the end of the sixth week in the self-esteem section results, again the intergroup difference was not statistically significant $(p=0.63)$ (Table 3).

The KINDL scale scores of the parents estimated following dietary therapy showed a nonsignificant increase in physical well-being, self-esteem, school subscale and total scores compared to baseline ( $p>0.05)$. KINDL subscale scores of the parents concerning family and peer relationships were lower after dietary therapy without any significant intergroup difference ( $p>0.05)$ (Table 4$)$. As the test for normality failed to allow for a $t$ test, as a nonparametric test, Wilcoxon signed-ranks test was 
used in the evaluation of the emotional well-being dimension. There was a positive, but a nonsignificant increase in emotional well-being subscale scores after the dietary therapy $(p=0.49)$.

\section{DISCUSSION}

IBS is a functional disease of the intestines characterized by chronic abdominal pain, which cannot be explained by an organic pathology, and changes in bowel habits which resolve with defecation. It forms a large part of the group known as functional gastrointestinal diseases. The main symptoms of this disease, whose pathophysiology has not yet been fully clarified, are chronic abdominal pain, changes in stool character and frequency, and bloating, together with abdominal distention ${ }^{(11)}$.

Sample size was calculated as 30 patients. However, this goal was not achieved in IBS patients followed up between December 2016 and December 2017. The number of patients may have been low due to the non-compliance to a strict dietary therapy, and the lower incidence of functional gastrointestinal disorders (FGID) in childhood. In the literature, there are still few studies performed with pediatric patients and the number of patients recruited is around 30 (12). According to the result of the power analysis of the study based on a one tailed hypothesis, statistical power of the study was found to be 32 percent. Since no other study cited in the literature used the FODMAP diet in pediatric IBS patients, our study is particularly important as being a pilot study.

As a general application of diet in the studies, the patients did not consume high-FODMAP foods for 2 weeks and and these food types were added to the diet gradually at the end of 2 weeks ${ }^{(10)}$. In adult studies, the duration of the full high FODMAP diet was longer (about 21 days). The reason for this may be the concerns about the deterioration of dietary continuity in pediatric patients. Especially in childhood, the duration of the diet cannot be extended. In addition, unfortunately, there is no information about the duration of the diet even in our classic textbooks. Total duration of dietary therapy is around 6-8 weeks in adult reviews.
Most of the studies with irritable bowel syndrome and FODMAP diet consist of adult studies ${ }^{(5,6,13,14)}$. In these studies, when the new dietary therapy was used in patients with IBS, there was a decrease in GIS symptoms primarily including abdominal pain and urgent defecation. Similar to the results of the present study. Halmos et al. have found positive responses using the low FODMAP diet in the adult patient group, particularly complaining with nausea and intestinal passage, with a concomitant significant improvement in the frequency and form of defecation in IBS, where diarrhea was at the forefront ${ }^{(5)}$. In our study, consistent with findings in the literature, $40 \%$ of the patients initially complained of diarrhea that did not persist after dietary therapy.

In our study, the rates of symptomatic improvement were $50 \%$ for abdominal pain, $100 \%$ for diarrhea and $80 \%$ for constipation. In a study conducted in 29 patients with functional intestinal disease in the pediatric age group, improvement was observed in $77 \%$ of patients with abdominal pain, $87 \%$ of those with diarrhea, $85 \%$ of those with constipation after the FODMAP diet ${ }^{(12)}$. In another randomized controlled double-blind study performed with 33 pediatric IBS patients, clinical responses of the patients to the FODMAP diet and the relationship between this response and intestinal microbiome biomarkers were investigated ${ }^{(9)}$. In this study as in ours, it was observed that abdominal pain episodes decreased after the FODMAP diet. In addition, response to the diet has been shown to be better in patients with a high intestinal microbiome, and it has been suggested that microbiota may be important in the pathophysiology of and clinical response in IBS.

Irritable bowel disease, like many other chronic diseases, is thought to negatively affect the quality of life. In many studies, the quality of life has been shown to be lower in children with both functional and organic GIS disease compared to healthy children. In this study, the KINDL scale, which was validated in Turkish and developed as a general-purpose quality of life assessment for children, was preferred ${ }^{(7)}$. In a study performed by Pederson et al. with 19 adult IBS cases, cases were evaluated with IBS-SSS (Irritable Bowel Syndrome Symptom Severity Scale) and IBS- 
QoL (Irritable Bowel Syndrome Quality of lifeScale), and a decrease in symptoms during the dietary therapy was observed, along with a concomitant increase in the quality of life scores ${ }^{(15)}$. In our study, results similar to those of this pilot study were obtained as a result of querying about symptoms and evaluating them using the KINDL scoring system

The KINDL scoring made two weeks after the end of dietary therapy demonstrated that physical wellbeing, emotional well-being, family, school and total KINDL scores and averages increased, and a significant $p$ value was observed in the results related to emotional well-being, family relationships and the total scale $(p<0.05)$. In the self-esteem and friendship sections, the repeatedly lower KINDL scale scores were not found to be significant. This fact may suggest that more time should be spent for the treatment of these patients so as to estimate the the impact of dietary therapy on their social lives. In addition, a conclusion could be drawn that aspects of physical well-being are partly more objective findings and that other subscales may be affected by the duration of the dietary therapy. The problems experienced during the day and mood changes that took place should be taken into consideration when evaluating results.

In a study using the Pediatric Quality of Life Questionnaire (PedsQL), which also covered functional GIS patients, the quality of life of patients was found to be lower for GIS patients than for the healthy group ${ }^{(16)}$. In our study, general quality of life scores, which were lower before the diet, increased after the dietary therapy, and the increases in the subscale scores related to emotional well-being and family dimensions were statistically. The negative relationship between age and the total KINDL scale scores may be attributable to a better ability to understand complaints and to respond to questions asked by the older people.

The first KINDL scale scores calculated at the beginning of treatment were higher in parents than in children. From a study using PedsQL on 25 functional GIS patients, when a questionnaire was applied to the family and the patient, the quality of life scores assessed by the parents were shown to be significantly worse than those reported by the children ${ }^{(17)}$. Our study did not show similarity with the literature in this aspect. At the end of the diet, the total KINDL scale scores and their averages calculated in the mothers were higher than in the first questionnaires. While increases were observed in the subscale scores of physical well-being, emotional well-being, self-esteem and school performance, relatively lower values were observed in dimensions of the family and friend relationships. We concluded that the results were not significant due to the fact that they were very close to each other and that there were few patients.

Adaptation and uninterrupted compliance to diet in the pediatric patient group is more difficult than in the adult group. This fact, and the scarcity of patients are the limitations of the study. In addition, nonrandomization of the patients is another limitation of the study.

\section{CONCLUSION}

After use of the low FODMAP diet in our study, an improvement was noticed in gastrointestinal system symptoms and in the affected quality of life of the patients. However, we think that studies involving larger groups with longer follow-up periods are needed to determine the effects of low FODMAP diet therapy on duration and long-term symptoms in children with the diagnosis of IBS.

As the T-test failed to meet the conditions, the Wilcoxon signed-ranks test, a nonparametric measurement, was used to evaluate the self-esteem section. There were negative findings at the end of the 6 th week in the results of the self-esteem section, but without any statistically significant intergroup difference $(p=0.63)$.

Ethics Committee Approval: For the study, İzmir Güney Public Hospitals Union, University of Health Sciences. Approval was obtained from University of Health Sciences Behçet Uz Pediatrics and Surgery Training and Research Hospital Clinical Research Et- 
hics Committee on 08.12.2016 and 2016 / 16-04.

Conflict of Interest: The authors have not declared any potential conflicts of interest.

Funding: No financial support has been received from any institution for this research.

Informed Consent: Patient permissions for this study were obtained from the parents of the patients.

\section{REFERENCES}

1. Sökücü S, Saner G, Durmaz Ö. Sindirim Sistemi ve Hastalıkları. In Neyzi O, Ertuğrul T, editorler. Pediyatri. Nobel Tıp Kitapevi, 2010;906-15.

2. Bradesi S, Mc Roberts JA, Anton PA, et al. Inflammatory bowel disease and irritable bowel syndrome: Separate or unified. Curr Opin Gastroenterol. 2003;19:336-42. https://doi.org/10.1097/00001574-200307000-00003

3. Apley J, Naish N. Recurrent abdominal pains: A field's survey of 1000 school children. Arch Dis Child. 1958;33:165-70. https://doi.org/10.1136/adc.33.168.165

4. Hyams JS, Burke G, Davis, et al. Abdominal pain and irritable bowel syndrome in adolescents: A community-based study. J Pediatr. 1996;129:220-6. https://doi.org/10.1016/S0022-3476(96)70246-9

5. Halmos EP, Power VA, Shepherd SJ, et al. A diet low in FODMAPS reduces symptoms of irritable bowel syndrome. Gastroenterology 2014;49:67-75. https://doi.org/10.1053/j.gastro.2013.09.046

6. de Roest RH, Dobbs BR, Chapman BA, et al. The low FODMAP diet improves gastrointestinal symptoms in patients with irritable bowel syndrome. a prospective study. Int J Clin Pract. 2013;67:895-903. https://doi.org/10.1111/ijcp.12128

7. Eser $E$, Yüksel $H$. Çocuklar için genel amaçlı sağlıkla ilgili yaşam kalitesi ölçeği Türkçe sürümünün psikometrik özellikleri. Türk Psikiyatri Dergisi. 2008;19:409-17.

8. Devanarayana M, Rajindrajith S, Benninga M. Quality of life and health care consultation in 13 to 18 year olds with abdominal pain predominant functional gastrointestinal diseases. BMC Gastroenterology. 2014;14:150. https://doi.org/10.1186/1471-230X-14-150

9. Böhn L, Störsrud S, Liljebo T. Diet low in FODMAPs reduces symptoms of irritable bowel syndrome as well as traditional dietary advice: A randomized controlled trial. Gastroenterology. 2015;149:1399-407. https://doi.org/10.1053/j.gastro.2015.07.054

10. Shepherd SJ, Parker FC, Muir JG, et al. Dietary triggers of abdominal symptoms in patients with irritable bowel syndrome: Randomized placebo-controlled evidence. Clin Gastroenterol Hepatol.2008;6:765-71. https://doi.org/10.1016/j.cgh.2008.02.058

11. Öhman L,Simren M. New insights into the pathogenesis and pathophysiology of irritable bowel syndrome. Dig Liver Dis. 2007;39:201-15. https://doi.org/10.1016/j.dld.2006.10.014

12. Brown SC, Whelan K, Gearry RB, Day AS. Low FODMAP diet in children and adolescents with functional bowel disorder: A clinical case note review. JGH Open.2019;4:153-9. https://doi.org/10.1002/jgh3.12231

13. Vanner SJ, Depew WT, Peterson WG. Predictive value of the Rome criteria for diagnosing the irritable bowel syndrome. Am J Gastrenterol. 1999;94:2803-7. https://doi.org/10.1111/j.1572-0241.1999.01437.x

14. Tuck CJ, Muir JG, Barrett JS, et al. Fermentable oligosaccharides, disaccharides, monosaccharides and polyols: Role in irritable bowel syndrome. Expert Rev Gastroenterol Hepatol. 2014;8:819-34. https://doi.org/10.1586/17474124.2014.917956

15. Pedersen N, Vegh Z, Burisch J, et al. Ehealth monitoring in irritable bowel syndrome patients treated with low fermentable oligo-, di-, mono-saccharides and polyols diet. World J Gastroenterol. 2014;20:6680-4. https://doi.org/10.3748/wjg.v20.i21.6680

16. Varni JW, Bendo CB, Nurko S. Health-related quality of life in pediatric patients with functional and organic gastrointestinal disorders. The Journal of Pediatrics. 2015;166:85-90. https://doi.org/10.1016/j.jpeds.2014.08.022

17. Carlson M, Moore C, Tsai C. Child and parent perceived food induced gastrointestinal symptoms and quality of life in children with functional gastrointestinal disorders. J Acad Nutr Diet. 2014;114:403-13. https://doi.org/10.1016/j.jand.2013.10.013 